\title{
TRANSVERSAL COMPETENCES AND CHARACTER EDUCATION IN LATVIA: NEEDS ANALYSIS REPORT
}

\begin{abstract}
A part of the intellectual output 1 "Needs analysis report" elaborated within the Erasmus+ project "Supporting teachers for developing intra-personal competencies and character education at school (ARETE CATALYST)", 2017-1-LV01-KA201-035435
\end{abstract}

Svetlana Surikova \& Tamāra Pīgozne

June 2018

Riga, Latvia 


\begin{abstract}
Authors:
Dr. paed. Svetlana Surikova, University of Latvia, Latvia

Dr. paed. Tamāra Pīgozne, University of Latvia, Latvia
\end{abstract}

Scientific advisor: Dr. paed. Manuel-Joaquín Fernández-González, University of Latvia, Latvia

The national report "Transversal competences and character education in Latvia: Needs analysis report" is a part of the transnational intellectual output 1 "Needs analysis report" elaborated within the Erasmus+ project "Supporting teachers for developing intra-personal competences and character education at school (ARETE CATALYST)", 2017-1-LV01-KA201-035435. The research report is structured in four parts as follows: 1) A detailed description of transversal competences and character education in Latvia; 2) Case studies of best practices in Latvia; 3) Benchmarking of transversal competences and character education in UK and USA; 4) Developing pupils' intrapersonal competencies and character education at school: bases for a support program for teachers in Latvia.

The content of this report does not reflect the official opinion of the European Union. Responsibility for the information and views expressed therein lies entirely with the authors.

\title{
Contents
}

Part 1: The context of transversal competences and character education (TC\&CE) in Latvia: lights and shadows.........................................................................2

Section 1.1: Information about the understanding of TC\&CE in Latvia...................2

Section 1.2: The existing TC\&CE initiatives in Latvia............................. 12

Part 2: Case studies of best practices in Latvia.........................................16

Section 2.1: Case studies in Latvia..................................................

The case study 1: Support to positive behaviour.............................

The case study 2: Character education program in Riga Catholic Gymnasium.......20

Part 3: Benchmarking of TC\&CE...........................................................27

Section 3.1: Some existing TC\&CE initiatives in UK and USA.....................27

Section 3.2: Some possibilities for transfer and adaptation of UK and USA materials and programs

Part 4: Developing pupils' intrapersonal competencies and character education at school: bases for a support program for teachers.............................................. 34

Section 4.1: SWOT analysis of TC\&CE in Latvia: synthesis of context analysis and benchmarking. 


\title{
Part 1
}

\section{The context of transversal competences and character education (TC\&CE) in Latvia: lights and shadows}

\author{
Section 1.1
}

\section{INFORMATION ABOUT THE UNDERSTANDING OF TC\&CE IN LATVIA}

\section{$\underline{\text { Understanding of transversal competences }}$}

The understanding of transversal competences (further in the text - TC) in Latvia is based on the document "Education for modern competence: description of study content and approach" (in Latvian: "Izglītība mūsdienīgai lietpratībai: mācību satura un pieejas apraksts") which defines the student's

virtues

and

transversal

competences

(http://www.izm.gov.lv/images/aktualitates/2017/Skola2030Dokuments.pdf). This document was elaborated in 2017_within the European Structural Fund (ESF) project "Competence-based approach in the educational content" - School 2030 (2016-2021), No. 8.3.1.1/16/I/002 (https://www.skola2030.1v/par-projektu). According to the above-mentioned document, the TC include significant students' cognitive, affective and social aspects that apply to all human activities. The TC help to acquire knowledge in different contexts and by different ways of thinking and selfdirected learning techniques, thus enhancing the link between new knowledge and personal experience. In turn, the use of the TC in different teaching/learning fields strengthens students' ability to use them independently and in a wide variety of situations, including complex and unpredictable situations. The students should improve such TC as:

\section{Self-knowledge and self-management}

A student recognizes himself/herself as an individual, his/her desires, needs and interests; is able to manage this/her emotions, develops positive relationships, formulates realistic goals, and makes responsible decisions; knows and is motivated to learn and improves himself/herself constantly and independently; understands and follows his/her learning process, evaluates his/her learning outcomes, recognizes the most effective learning pathways, plans the learning process, and assumes responsibility for it. The student acquires different learning, self-management, emotion management 
and motivation strategies, that help to structure thinking and behavior so that he/she can independently set goals, plan his/her attainment, observe his/her own progress, make changes, and evaluate the learning process and results in all spheres of life.

\section{Thinking and creativity}

The student identifies, analyses, and evaluates the situations and information, and acts:

- using effective problem-solving strategies in complex situations;

- using economic and social context opportunities, purposefully creating new ideas and products, and finding innovative solutions;

- planning and implementing the ideas in practice, taking initiative and leadership, when it is needed;

- developing the virtues and habits that characterize the creative, curious and critical minded personality, and promoting the creation of a new environment for stimulating new solutions.

\section{Collaboration and participation}

By collaborating, the student creates persistent social habits in his/her communication with peers, focusing on the commonly achieved result; learn skills for communication, understanding and cooperation in heterogeneous groups, reaching a consensus point on disputed issues and agreeing on a coherent action towards common goals to be achieved. The student does not just knows how to collaborate, but also wants to collaborate with peers, and he/she has a stable habit of solving interpersonal communication problems, searching for and showing opportunities for observing and harmonizing different needs, interests and beliefs.

By participating, the student thinks and acts as a responsible citizen of the society; taking into account diverse interests, s/he evaluates, co-operates with others, and collectively tackles controversial and complex issues that affect society's present, future and sustainable development without endangering future generations and their needs.

\section{Digital Skills}

Digital skills are a set of knowledge, skills, attitudes, abilities and awareness in working with digital technologies, including: performing tasks and solving problem related to communication and cooperation; obtaining and organizing information; content creation and sharing; effective, responsible, critical, creative, independent design of knowledge; and ability to understand the role of digital technology in constructing of reality. Digital skills describe a student's ability to use digital technology to perform the tasks mentioned above, and they ensure the student's ability to act in the information society. 
According to Latvia's Report on Terminology (2016, p. 18) elaborated within the EC project „European Qualifications Framework - National Coordination Point” (572373-EPP-1-2016-1-LVEPPKA3-EQF-NCP), "the transversal competences are the skills that are learned gradually and supplemented in different learning situations, subjects and courses at an educational institution and / or in leisure time" (http://www.nki-latvija.lv/content/files/Terminologijas_zinojums_2016.pdf)

The Latvian teachers improve their understanding on the TC regularly during various training and professional development seminars and courses (read more in the section on the existing TC\&CE initiatives in Latvia).

\section{Understanding of character education}

In 2015, the Latvian parliament (Saeima) gave final approval to amendments to the education law that mean schools will henceforth be obliged to give children 'moral education' in line with the values of the Constitution, most notably with regard to the primacy of conventional ideas of what constitutes marriage and family life. https://eng.1sm.lv/article/society/society/saeima-approves-lessons-inconstitutional-morality-for-schoolchildren.a134466/ The work group created by the National Center for Education (VISC) of the Republic of Latvia tasked with working out "moral upbringing (virtue education) guidelines" corresponding to the controversial education law amendments; has been offered the following virtues for inclusion in the guidelines: respect, solidarity, justice, virtue, fairness, freedom, responsibility, studiousness, caring, empathy, moderation and courage. The guidelines also feature concepts such as life, work, and culture. https://eng.lsm.lv/article/society/society/morality-guidelines-work-group-discusses-nine-

virtues.a159698/; https://eng.1sm.lv/article/society/society/courage-and-moderation-join-upbringingguidelines.a167479/

In 2016, the Cabinet of Ministers' regulation No 480 'Guidelines for the upbringing (virtue education) of learners and the procedure for evaluating information, teaching aids, materials and teaching/learning and upbringing methods" (In Latvian: "Izglītojamo audzināšanas vadlīnijas un informācijas, mācību lìdzekl̦u, materiālu un mācību un audzināšanas metožu izvērtēšanas kārtība") was adopted https://ikumi.lv/ta/id/283735-izglitojamo-audzinasanas-vadlinijas-un-informacijas$\underline{\text { macibu-lidzeklu-materialu-un-macibu-un-audzinasanas-metozu-izvertesanas }}$

In April-May 2018, within the ARETE CATALYST project the web-based survey was organised in order to clarify the understanding of character education in Latvian educational context. The following respondents' groups were involved in the research with a total response rate $97 \%$ (see Table 1). 
Table 1. The research sample

\begin{tabular}{llll}
\hline Respondents' group & Representative sample & Real sample & Response rate \\
\hline In-service teachers & 150 & 110 & $73 \%$ \\
\hline School leading staff & 100 & 53 & $53 \%$ \\
\hline School students & 150 & 222 & $148 \%$ \\
\hline Parents & 150 & 190 & $127 \%$ \\
\hline Regional authorities & 20 & 10 & $50 \%$ \\
\hline Pre-service teachers & 150 & 110 & $73 \%$ \\
\hline Other & - & 5 & $97 \%$ \\
\hline
\end{tabular}

For quantitative data processing and analysis, the calculation of the mean of the total sample and subsamples as well as comparison between the different respondents' groups (using Kruskal-Wallis Test) were conducted; the differences in pairs between the groups were evaluated according to the Bonferroni correction. The results of these tests will be used for elaboration of scientific papers. For the purpose of this report, frequency tables and crosstabs were employed to provide reader-friendly content and visualisation.

As it can be seen in Figure 1, respondents believe that it is relatively clear to them what the notions 'character' and 'virtue' mean, also they believe that their understanding of the concept "character" (43.3\% absolutely agree and $25.6 \%$ agree) is better than the understanding of "virtue" (30.7\% absolutely agree and $31.3 \%$ agree). Both concepts are perceived as the notions which have not the same meanings (40.7\% absolutely agree and $22.0 \%$ agree). In general respondents also agree that virtue is not only a religious notion (49.4\% absolutely agree and $20.1 \%$ agree) as well as that character education and virtue education are not the same (34.7\% absolutely agree and $21.7 \%$ agree).

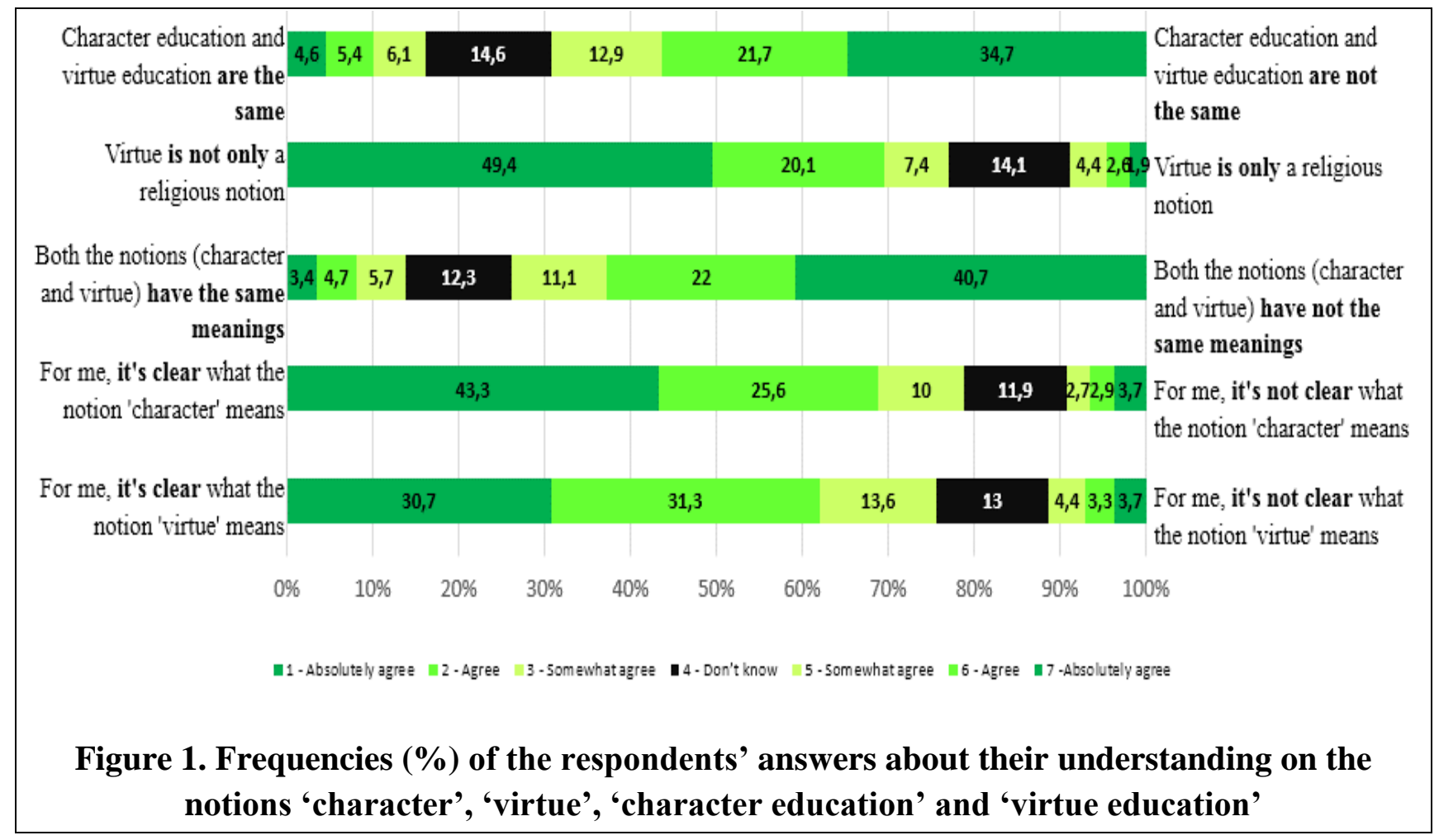


Looking at differences among groups regarding these questions, $37.5 \%$ of school students, $19.9 \%$ of in-service teachers and $22.7 \%$ of parents are hesitating or agree (with different strength degrees) to say that the meaning of the concept 'virtue' is not clear for them (see Figure 2) and $27.3 \%$ of preservice teachers and $28.4 \%$ of school students - to say that the meaning of the concept 'character' is not clear for them (see Figure 3).

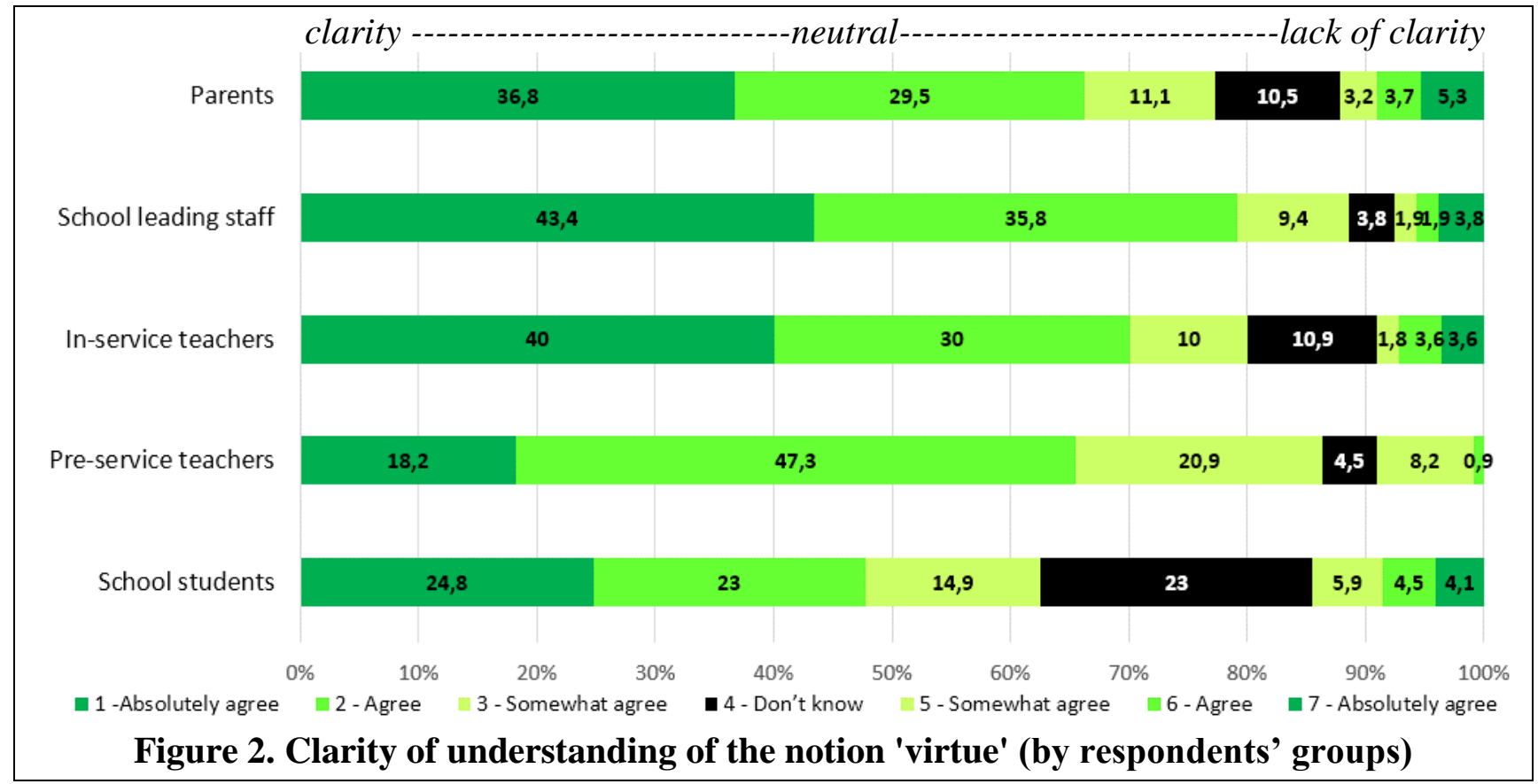

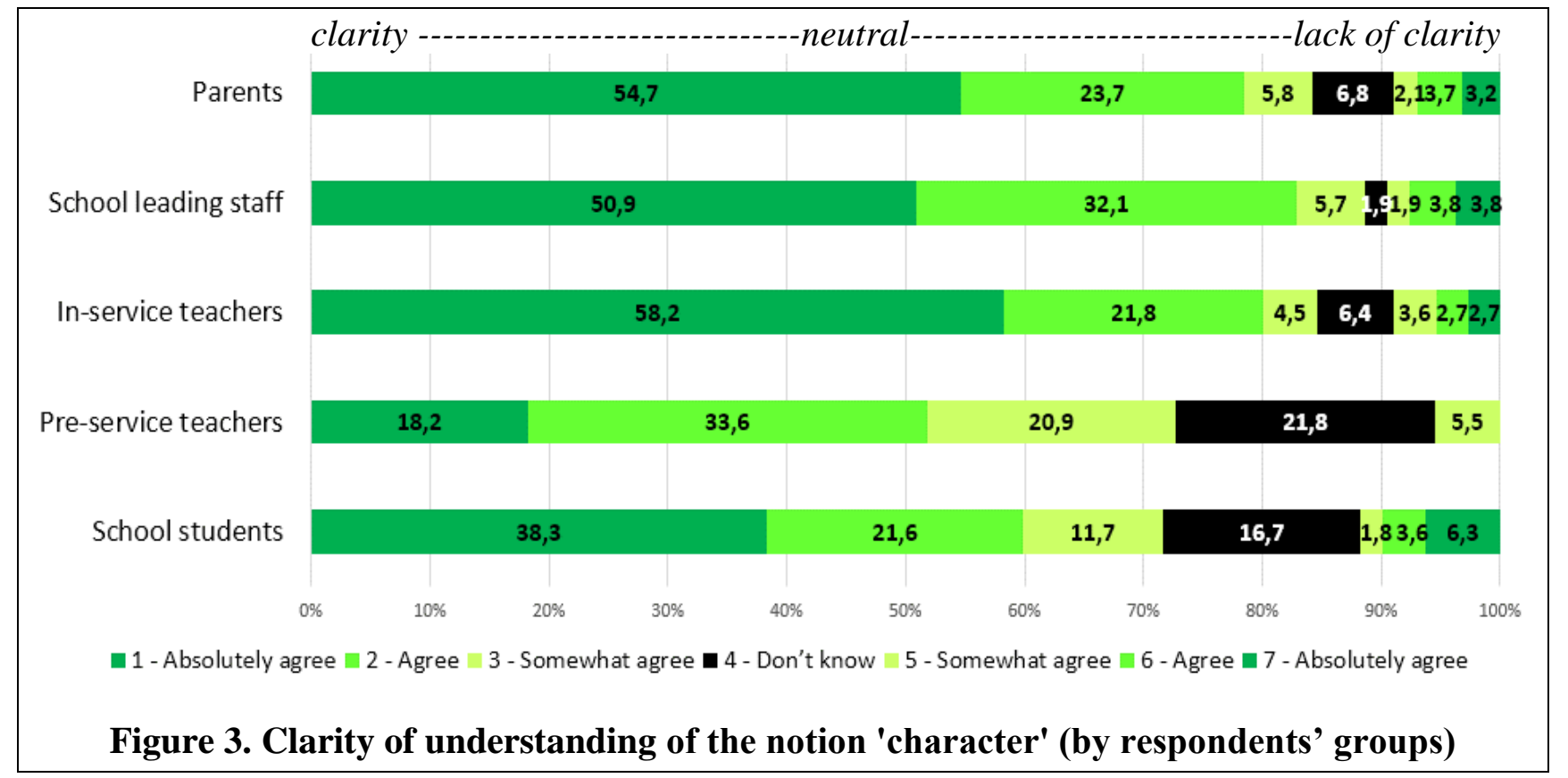

Both concepts are perceived as the notions which have different meanings, especially in parents' mind (61.1\% absolutely agree) (see Figure 4$)$. 


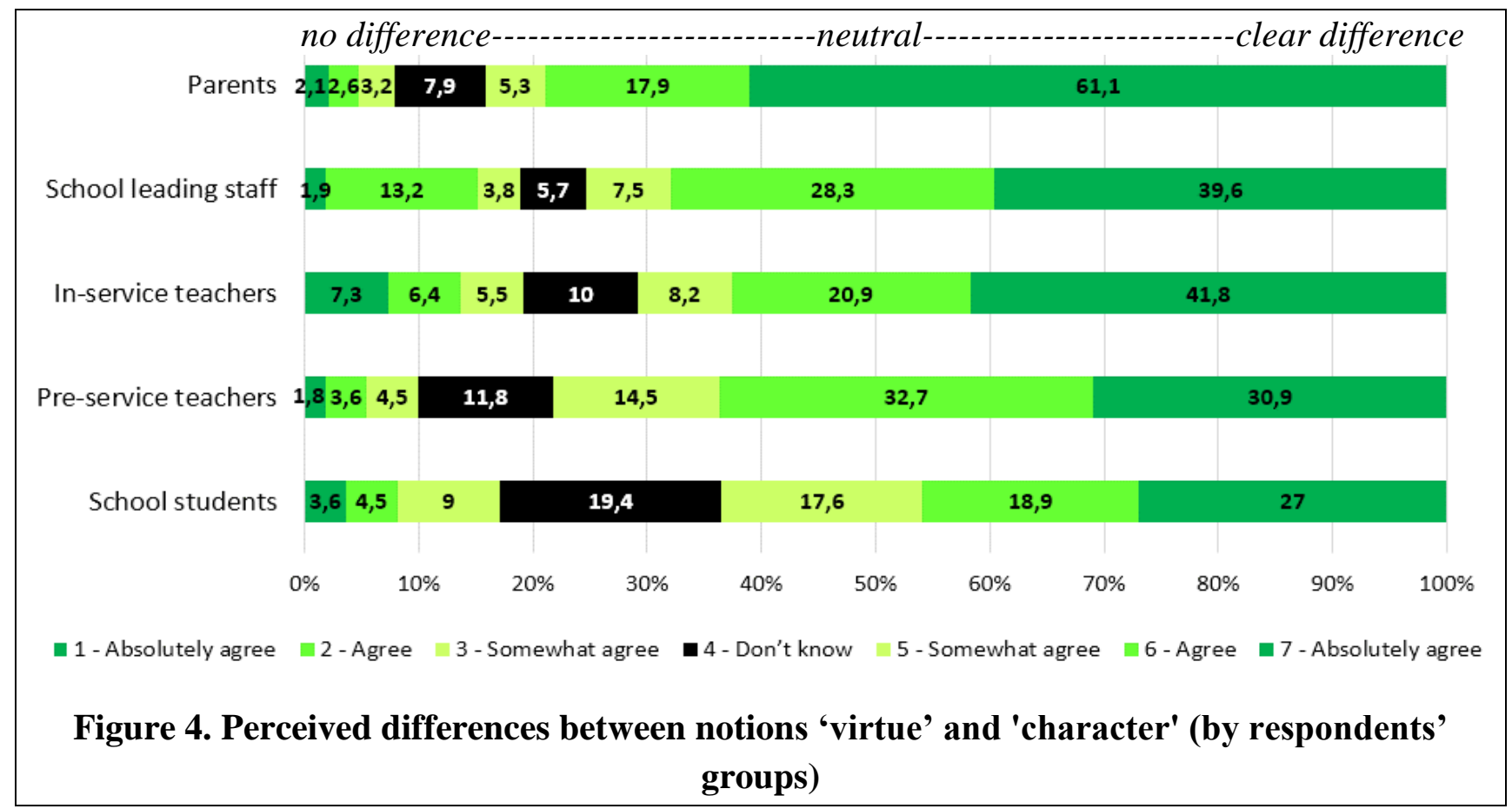

'Virtue' is emphasized as being not only a religious concept, but school students agree slightly less with this statement than the other respondents' groups (see Figure 5).

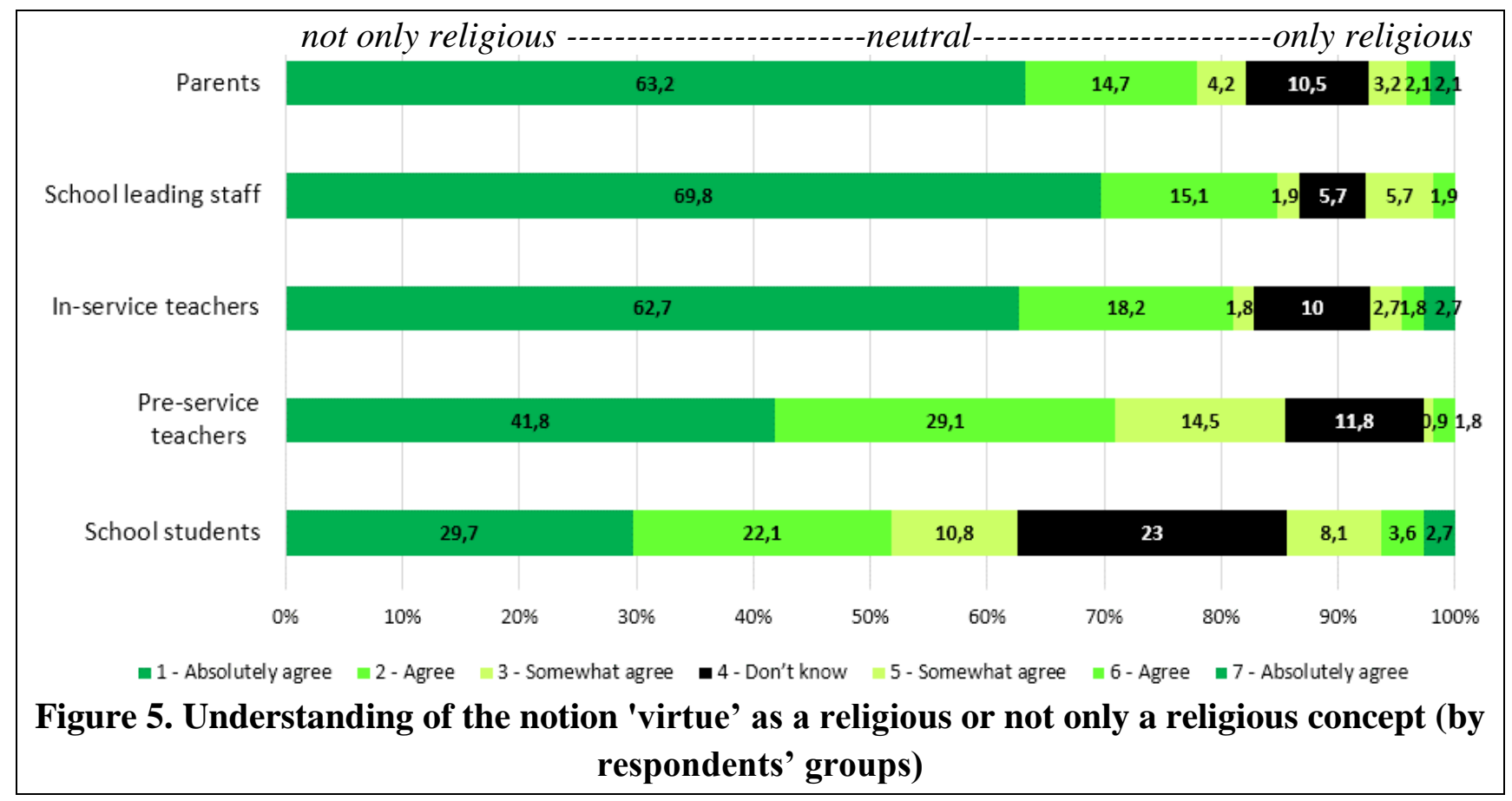

By answering whether 'character education' and 'virtue education' are the same, it is difficult for $23 \%$ of school students to formulate their opinions, while pre-service teachers, in-service teachers, school leading staff, and especially parents (51.6\% absolutely agree), are tended to think that 'character education' and 'virtue education' are not the same (see Figure 6). 


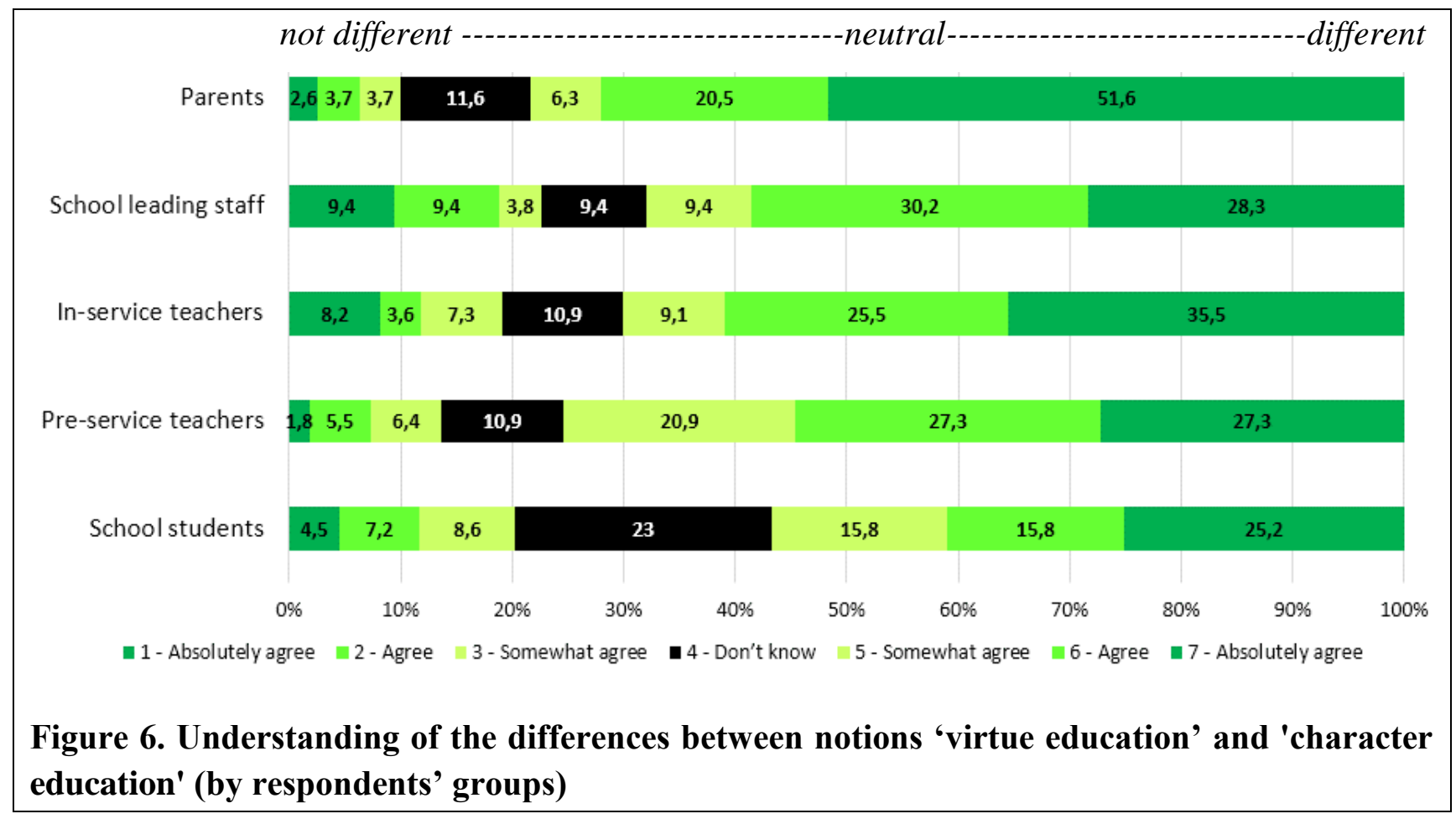

These results are in line with qualitative data presented by the respondents' self-generated expressions regarding their understanding of 'character education' and 'virtue education' and the differences between them (see Table 2).

Table 2. Respondents' understanding about the differences between the notions 'character education' and 'virtue education'

\begin{tabular}{lllllll}
\hline & $\begin{array}{l}\text { Total } \\
(\mathbf{N = 7 0 0})\end{array}$ & $\begin{array}{l}\text { School } \\
\text { students } \\
(\mathbf{n = 2 2 2})\end{array}$ & $\begin{array}{l}\text { Pre- } \\
\text { service } \\
\text { teachers } \\
(\mathbf{n = 1 1 0})\end{array}$ & $\begin{array}{l}\text { In-service } \\
\text { teachers } \\
(\mathbf{n = 1 1 0})\end{array}$ & $\begin{array}{l}\text { School } \\
\text { leading } \\
\text { staff } \\
(\mathbf{n = 5 3})\end{array}$ & $\begin{array}{l}\text { Parents } \\
(\mathbf{n = 1 9 0})\end{array}$ \\
\hline $\begin{array}{l}\text { Character education and } \\
\text { virtue education are the } \\
\text { same or similar notions }\end{array}$ & $85(12.1 \%)$ & $43(19.4 \%)$ & $2(1.8 \%)$ & $15(13.6 \%)$ & $8(15.1 \%)$ & $17(8.9 \%)$ \\
\hline $\begin{array}{l}\text { Character education and } \\
\text { virtue education are not } \\
\text { the same }\end{array}$ & $493(70.4 \%)$ & $139(62.6 \%)$ & $90(81.8 \%)$ & $80(72.7 \%)$ & $31(58.5 \%)$ & $145(76.3 \%)$ \\
\hline $\begin{array}{l}\text { These two notions are } \\
\text { interconnected }\end{array}$ & $44(6.3 \%)$ & $7(3.2 \%)$ & $6(5.5 \%)$ & $8(7.3 \%)$ & $12(22.6 \%)$ & $10(5.3 \%)$ \\
\hline Lack of understanding & $60(8.6 \%)$ & $27(12.2 \%)$ & $7(6.4 \%)$ & $6(5.5 \%)$ & $2(3.8 \%)$ & $17(8.9 \%)$ \\
\hline No answer & $18(2.6 \%)$ & $6(2.7 \%)$ & $5(4.5 \%)$ & $1(0.9 \%)$ & - & $1(0.5 \%)$ \\
\hline
\end{tabular}

Regarding respondents' acceptance/rejection of character education and virtue education, overall, respondents have a favourable opinion and acceptance of both character education (CE) and virtue education (VE). This tendency is stronger regarding character education (in a 7-point Likert scale CE Mean=5.38; VE Mean=4.87). The average difference between VE and CE is of 0.5 points in a 7-point Likert scale (see Figure 7). When comparing the responses of different respondents' groups, it was specified that the tendency in the perception of differences by all groups is the same, the least difference in perception of both notions identified in the answers proposed by school leading staff. 


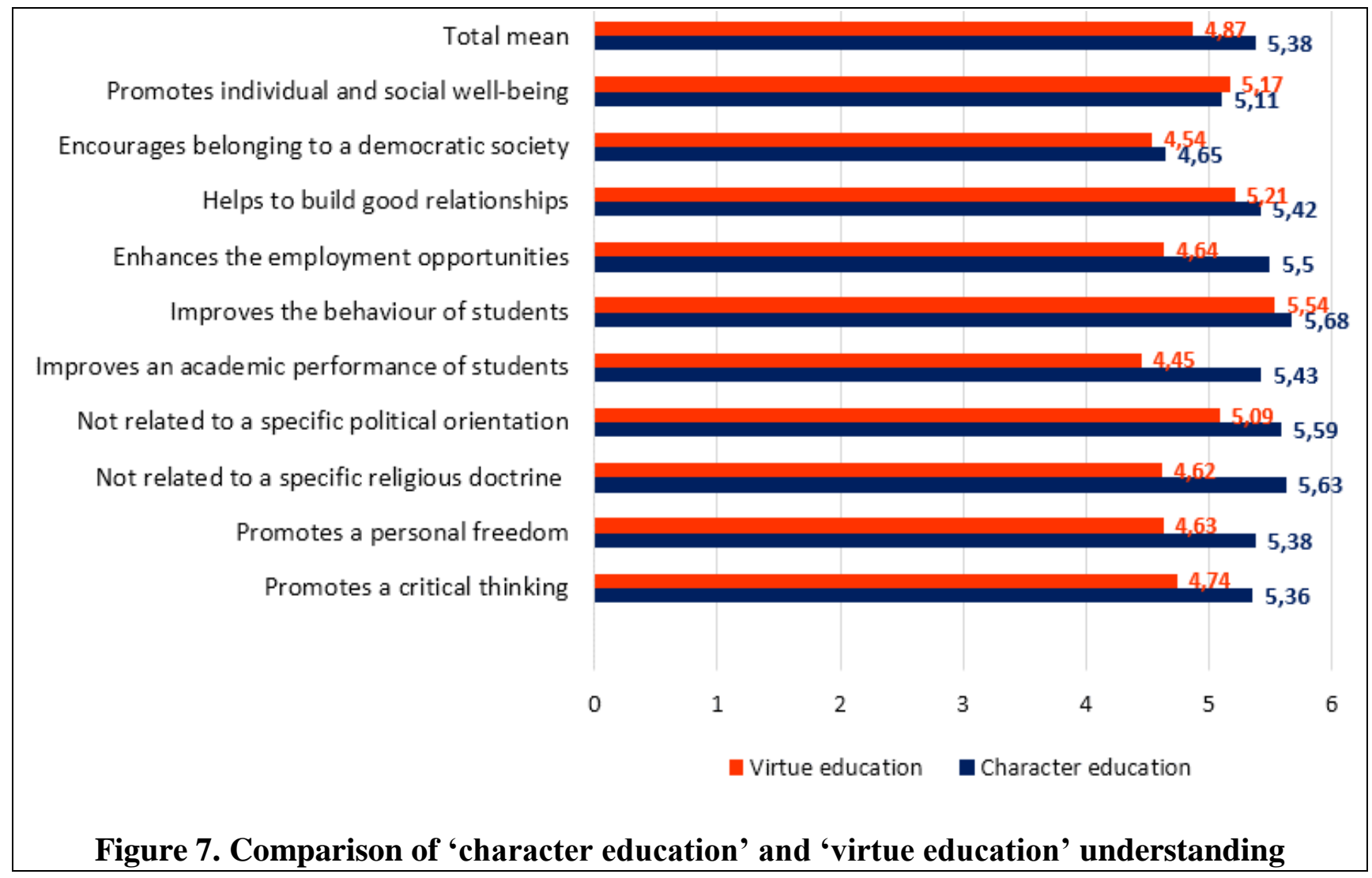

Regarding similarities between the perceptions of CE and VE, the highest rated indictor in both CE and VE was the help that they represent to improve behaviour (CE Mean=5.68; VE Mean=5.54). Respondents also rated the impact of both $\mathrm{CE}$ and VE for enhancing belonging to a democratic society as one of the lowest (CE Mean=4.65; VE Mean=4.54).

In addition to these similarities, some differences in understanding between character and virtue education appeared:

Regarding character education, respondents highly agreed that it is not associated with a specific religious doctrine or political orientation, but relates more to critical thinking, promotes personal freedom, improves students' academic performance and students' behavior and is more perceived as helping to build good relationships and enhancing the employment opportunities. The indicator related to the impact of character education on belonging to a democratic society received the weakest agreement $($ Mean= 4.65).

Regarding virtue education, respondents highly agreed that it helps to promotes both individual and social well-being. The indicator related to virtue education impact on higher academic performance received the weakest agreement $($ Mean $=4.45)$

In addition to these questions, in-service teachers and school leading staff were asked if they agree or not with seven different definitions of character education proposed to them. Definitions differed on the focus of character education (learning or teaching), and on the type of instruction (formal or non- 
formal). Overall, they mostly agree with all the definitions, and the level of agreement of both groups is similar. A comparison of frequencies for the 7 definitions was performed, merging both respondent groups (see Table 3).

Table 3. Comparing the frequencies within the in-service teachers' and school leading staff's understanding about the notion 'character education'

\begin{tabular}{|c|c|c|c|c|c|c|c|}
\hline \multirow{2}{*}{$\begin{array}{l}\text { Proposed definitions of character } \\
\text { education } \\
\text { "Character education..." }\end{array}$} & \multicolumn{2}{|c|}{ Focus } & \multicolumn{2}{|c|}{ Type } & \multirow{2}{*}{$\begin{array}{l}\text { Disagree } \\
(\%)\end{array}$} & \multirow{2}{*}{$\begin{array}{l}\text { Neither } \\
\text { agree nor } \\
\text { disagree } \\
(\%)\end{array}$} & \multirow{2}{*}{$\begin{array}{l}\text { Agree } \\
(\%)\end{array}$} \\
\hline & learning & teaching & formal & $\begin{array}{l}\text { non- } \\
\text { formal }\end{array}$ & & & \\
\hline $\begin{array}{l}\text { is a method of internal discipline } \\
\text { and motivation for students }\end{array}$ & $\mathrm{x}$ & & $\mathrm{x}$ & & 12.2 & 35.4 & 52.4 \\
\hline $\begin{array}{l}\text { implies a more deliberate approach } \\
\text { - a conscious decision to develop } \\
\text { certain students' virtues, } \\
\text { behaviours and attitudes and a plan } \\
\text { as to how this will be achieved }\end{array}$ & & $\mathrm{x}$ & $\mathrm{x}$ & & 11.6 & 37.2 & 51.2 \\
\hline is any form of moral education & & $\mathrm{x}$ & $\mathrm{x}$ & $\mathrm{x}$ & 12.2 & 52.4 & 35.4 \\
\hline $\begin{array}{l}\text { is a learning process that enables } \\
\text { students and adults in a school } \\
\text { community to understand, care } \\
\text { about and act on core ethical values }\end{array}$ & $\mathrm{x}$ & & $\mathrm{x}$ & & 10.4 & 43.9 & 45.7 \\
\hline $\begin{array}{l}\text { is the intentional, proactive effort } \\
\text { by schools, districts, and states to } \\
\text { instill in their students important } \\
\text { ethical values }\end{array}$ & & $\mathrm{x}$ & $\mathrm{x}$ & & 10.4 & 48.8 & 40.9 \\
\hline $\begin{array}{l}\text { is the long term process of helping } \\
\text { young people develop good } \\
\text { character, i.e., knowing, caring } \\
\text { about, and acting upon core ethical } \\
\text { values }\end{array}$ & $\mathrm{x}$ & & & $\mathrm{x}$ & 15.9 & 22.6 & 61.6 \\
\hline $\begin{array}{l}\text { are the explicit and implicit } \\
\text { educational activities that help } \\
\text { young people develop a good } \\
\text { character }\end{array}$ & $\mathrm{x}$ & $\mathrm{x}$ & $\mathrm{x}$ & $\mathrm{x}$ & 14.0 & 33.5 & 52.4 \\
\hline
\end{tabular}

In the assessment of the definitions, in-service teachers and school leading staff are tended to give affirmative answers, in general more likely agreeing to definitions with focus on learning or rather neutrally perceiving the proposed definitions with focus on teaching, especially such as "character education is any form of moral education".

Summarizing this section, it can be said that in Riga educational system there is a general agreement of all sectors (parents, pupils, pre-service and in-service teachers, and school leaders) to say that character and virtue are quite well-known concepts, and that they are different, and therefore character education and virtue education are also different things, but they are interconnected, because virtue is not only a religious concept. Respondents have a quite favourable opinion and acceptance of both 
character education and virtue education, and this tendency is stronger regarding character education. Both kinds of education are particularly relevant to improve students' behaviour. Respondents particularly strongly agree that character education is not directly related to religious or political education, and that it enhances academic performance and employability, whereas virtue education is particularly helpful to build good relationships and promotes both individual and social well-being. Teachers and school leaders reported the highest agreement to definitions of character education that included both students' self-involvement and non-formal education activities. 


\section{Section 1.2}

\section{THE EXISTING TC\&CE INITIATIVES IN LATVIA}

The necessary education and professional qualifications for teachers in the Republic of Latvia and their professional competence development procedures are established in the Regulations No. 662 of 28 October 2014 by the Latvian Cabinet of Ministers. The teacher is responsible for the development of his professional competence, carried out within three years, not less than 36 hours and it is planned in co-operation with the heads of educational institutions in which the teacher carries out his teaching activities. The teacher can develop his professional skills studying A or B programme. The Regulations provide that B programmes are implemented only in higher educational institutions, while A programs can be delivered by education institutions, teachers' professional NGOs and institutions subordinated to the ministries. For example, Education and Information Services of Riga City implement A programmes.

The full A program should last maximum 36 hours in different modules. A-program modules should last at least six hours. 4 modules can be included in A programme: the module of teacher`s general competencies (which can include civic competence development), the module of curriculum and didactics, the module of the educational process management and the module of teacher's experience (participation in conferences, seminars, workshops, etc.). This last module includes also teacher personality development and elaboration of teaching/learning materials for use in the classroom.

The existing TC\&CE initiatives (projects, continuing education courses, programmes, seminars, etc.) for teachers' professional competence development

Several A program courses are proposed in Latvia in the field of transversal competences and virtues.

1. A teachers' training and professional development seminar "Improvement of a Teachers'

Professional Competence on the Issues of National and Virtue Education" (Level A, 6 acad.hours); in Latvian: A lìmeņa pedagogu profesionālās kompetences pilnveides programmas seminārs „Pedagogu profesionālās kompetences pilnveide valstiskās un tikumiskās audzināšanas jautājumos” (6 akad.st.) https://www.macibuiestade.lv/notikumi/pedagoguprofesionalas-kompetences-pilnveide-valstiskas-un-tikumiskas-audzinasanas-jautajumos

2. A teachers' training and professional development programme "Improvement of virtues in the upbringing process" (Level A, 6 h); in Latvian: A lìmeņa pedagogu profesionālās kompetences pilnveides programma "Audzināšanas procesā izkopjamie tikumi” (6 st.) https://lmc.lv/lv/jaunumi/atvert/sia-latgales-macibu-centrs--piedava-apgut--a-limena-pedagoguprofesionalas-kompetences-pilnveides-pr 
3. A teachers' training and professional development programme "Transversal competences in a civic and national education in a competence-based learning process" (Level A, $16 \mathrm{~h}$ ); in Latvian: A lìmeña pedagogu profesionālās kompetences pilnveides programma "Caurviju prasmes pilsoniskajā un valstiskajā audzināšanā uz kompetencēm balstītā mācību procesā" (16 st.) http://www.rv1g.lv/index.php/talakizglitiba/

4. A teachers' training and professional development programme "Understanding the concept of competence and acquiring the transversal competences in a preschool education" (Level A, 12 h); in Latvian: A lìmeņa pedagogu profesionālās kompetences pilnveides programma “Kompetences jēdziena izpratne un caurviju prasmju apguve pirmsskolā" (12 st.) http://lpmc.lv/macibas/backPid/7/category/pirmsskolu-darbiniekiem/article/kompetencesjedziena-izpratne-un-caurviju-prasmju-apguve-pirmsskola-3-dala-8marta.html

5. A teachers' training and professional development programme "Basic principles of successful upbringing within the aspect of value and virtue education" (Level A); in Latvian: A limeña pedagogu profesionālās kompetences pilnveides programma "Veiksmīgas audzināšanas pamatprincipi vērtībizglītības un tikumiskajā aspektā", http://lpmc.lv/macibas/backPid/7/browse/2/category/skolu-darbiniekiem/article/veiksmigasaudzinasanas-pamatprincipi-vertibizglitibas-un-tikumiskaja-aspekta-6decembri.html

6. Recently, the Education development centre, the leading non-profit nongovernmental organization in Latvia in the field of teachers' professional development, has launched a 36 hour program (A course) "Value education" about value education integration in the study process at school, and including transversal competences that are included in the educational reform plan such as critical thinking, problem solving, collaboration, participation (http://www.iac.edu.lv/programmas/new-program-page/)

There are other teacher training initiatives in this field which are not part of compulsory professional development courses, as for example:

7. An off-site seminar at Lielvarde Elementary School "Teachers' collaboration to implement the competence-based approach. Development of the transversal competence (thinking and creativity) in the Latvian language and literature lessons at the elementary school" (8 h); in Latvian: Izbraukuma seminārs uz Lielvārdes pamatskolu "Skolotāju sadarbība kompetenču pieejas ieviešanā. Caurviju prasmes (domāšana un radošums) attīstī̌̌ana latviešu valodas un literatūras stundās pamatskolā" (8 st.) http://riimc.lv/lv/events/izbraukuma-seminars-uz$\underline{\text { lielvardes-pamatskolu-skolotaju-sadarbiba-kompetencu-pieejas-ieviesana-caurviju-prasmes- }}$ domasana-un-radosums-attistisana-latviesu-valodas-un-literaturas-stundas-pamatskola/1692 
8. A methodological afternoon seminar at Riga Classical Gymnasium "Developing the transversal competence - thinking and creativity - in the Latvian as the second language and literature lessons" (5 h); in Latvian: Metodiskā pēcpusdiena Rīgas Klasiskajā gimnāzijā "Caurviju prasmes - domāšana un radošums - attīstī̌sana latviešu kā otrās valodas un literatūras stundās" (5 st.) http://riimc.lv/lv/events/metodiska-pecpusdiena-rigas-klasiskaja-gimnazija-caurvijuprasmjes-domasana-un-radosums-attistisana-latviesu-ka-otras-valodas-un-literaturas$\underline{\text { stundas } / 1673}$

9. A teachers' training and professional development course "Transversal competences to realise the competence-based education" (8 h); in Latvian: Kurss pedagogu profesionālās kompetences pilnveidei “Caurviju prasmes kompetenču izglītības īstenošanai” (8 st.) http://vitae.lv/wpcontent/uploads/2017/02/Laura-Mikelsone-caurvijas.pdf

10. A teachers' training and professional development within the project "Competence-based approach in the educational content", in Latvian: Pedagogu profesionālā pilnveide projekta “Kompetenču pieeja mācību saturā” (2016-2021) ietvaros https://www.skola2030.lv/parprojektu

Other TC\&CE initiatives (projects, conferences, workshops, documents, etc.) for children, youth, parents, teachers, etc.

1. Erasmus+ project "Shaping Characters" (No. 2015-1-UK01-KA201-013749, PVS ID 3490) with three partners from Latvia: Education, Culture and Sports Department of Riga Municipality, Riga Secondary School No 64 and Latvian non-formal organization for young people "Young Folks LV". http://www.shapingcharacters.eu;

http://www.iksd.riga.lv/public/88494.html

2. The document "Education for modern competence: description of study content and approach" (in Latvian: "Izglītība mūsdienīgai lietpratībai: mācību satura un pieejas apraksts") which defines the pupil's purposes (e.g. virtues and transversal competences) http://www.izm.gov.lv/images/aktualitates/2017/Skola2030Dokuments.pdf is elaborated_within the ESF project "Competence-based approach in the educational content" (2016-2021), No. 8.3.1.1/16/I/002.

3. The article "A character education programme in Riga Catholic Gymnasium" published in the magazine "Education and Culture" on 9 February 2017 and online; in Latvian: Lolita Ërgle. Rakstura izglītības programma Rīgas Katoḷ g gimnāzijā. Raksts publicēts laikrakstā "Izglītība un Kultūra" Nr.3, 2017. gada 9. februārī un tiešsaistē http://katolis.lv/biblioteka/tematiskaiskatalogs/katoliska-izglitiba/rakstura-izglitibas-programma-rigas-katolu-gimnazija.html 
4. A conference "Topical issues and trends of character education in Latvia and worldwide" on 28 April 2017 (in Latvian: "Raksturizglìtības aktualitātes un tendences pasaulē un Latvijā").

http://katolis.lv/notikumu-kalendars/backPid/369/category/seminari/article/konference-raksturaizglitibas-aktualitates-un-tendences-pasaule-un-latvija-1.html;

http://katolis.lv/zinas/backPid/30/category/latvija/article/rakstura-izglitiba-pamats-laiizaudzinatu-nakotnes-cilveku.html

5. A workshop "Character Education in Interdisciplinary Teaching" within the Teachers' conference in Riga, April 2013. Video: http://www.teachersconference.lv/portfolio-item/feyiobamehinti-character-education-in-interdisciplinary-teaching/

6. The National Center for Education (VISC) of the Republic of Latvia worked out the moral upbringing (virtue education) guidelines https://eng.lsm.lv/article/society/society/moralityguidelines-work-group-discusses-nine-virtues.a159698/; https://eng.1sm.lv/article/society/society/courage-and-moderation-join-upbringingguidelines.a167479/

7. The research sub-project "Teachers' ethics, development of transversal and socio-emotional competences and character education to promote quality of education" within the research project "Human, technologies and quality of education", 2016-2018 (Faculty of Education, Psychology and Art of the University of Latvia) https://www.pzi.lu.lv/petnieciba/lu-petniecibasprojekti/cilv-tehn-un-izgl-kval/1aspekts-cilveks-un-izglitiba/skolotaju-etika-un-transversalokompetencu-21-gs-prasmju-attistiba/

8. The research project "Modernization of school education in Latvia through an innovative research-based program on 21st century competences and virtue ethics development supported by a virtual campus (ARETE-school)", 2017-2020 (University of Latvia)

https://www.pzi.lu.lv/petnieciba/lu-petniecibas-projekti/izglitibas-modernizacija-latvijas-skolasarete-school/.

Summarizing, there is a number of teacher training initiatives in Latvia in the field of transversal competences and personality development. However, each one addresses only partially the different aspects of teacher professional development in the field of character education: some are theory oriented, other are oriented to the work in the classroom or in concrete subject matters (e.g., literature), some focus on a concrete kind of virtue (e.g., civic virtues, patriotism), others on the integration of values in the school life or in interdisciplinary aspects. There is a need for a teacher professional development program that integrates the 4 aspects to which the Latvian educational law refers: improvement of teachers' self-experience in the field, enhancement of communicative competence for creating a school culture, elaboration of methodical and didactic aspects, and school and class management aspects. 


\title{
Part 2
}

\section{Case studies of best practices in Latvia}

\author{
Section 2.1
}

CASE STUDIES IN LATVIA

\section{THE CASE STUDY 1: \\ Support to positive behaviour}
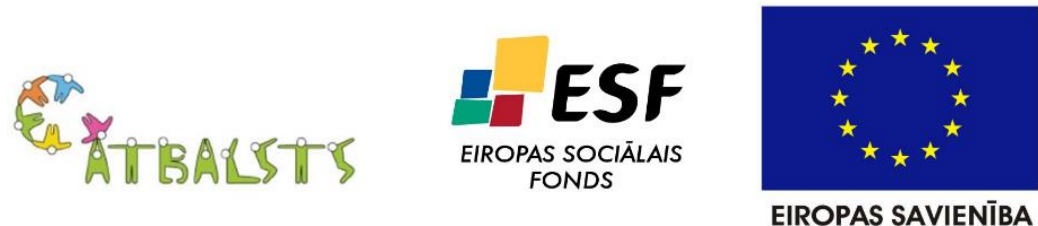

LATVIJAS

UNIVERSITATE

EIROPAS SAVIENİBA

\section{Preface:}

The subprogram „Support to Positive Behaviour” (SPB) has been developed within the project of European Structural Funds „Development and implementation of support programs for establishing a support system for young people under social exclusion risk" (2011-2013) and has been piloted in 39 educational institutions and 15 municipalities in Latvia in the time period from 2012 till 2014. The SPB is only one part of the research-based preventive support system for decreasing the social exclusion risk for children and young people from age 7 to 25 .

\section{The developers:}

The SPB was developed in 2011-2012 by the three Latvian experts (Baiba Martinsone, Dita Nìmante and Linda Daniela) according to the Latvian context and cultural environment as well as legislation.

\section{The theoretical framework:}

The SPB was developed on the basis of ideas expressed by:

- Lee and Merlin Canter (Canter \& Canter, 2001);

- Rudolf Dreikurs (Dreikurs \& Cassel, 1974, 1991, Dreikurs, Cassel \& Dreikurs-Ferguson, 2004, Dreikurs, Grunwald \& Pepper, 1998); 
- Jane Nelsen (Nelsen, Lott \& Glenn, 1997, Nelsen, 1987), etc.

- The foreign good practice examples such as:

- USA program: School-wide positive behavioural interventions \& supports;

- Norwegian program: Positive behaviour, interactions and learning environment in school;

- $\quad$ studies on the results and effectiveness of these programs (Sørlie \& Ogden, 2007; Sørlie \& Ogden, 2009; Sugai et al., 2000; Walker et al., 1996).

\section{The aim:}

To develop a common system for promoting positive behavior at school providing a systemic facilitation of positive students' behavior and decrease of behavior breaches at school thus in shortterm ensuring order at school while in long-term improving students' emotional and moral development

\section{The preconditions:}

The five groups of preconditions are needed to achieve the goal of the SPB:

Firstly, schools that want to implement SPB have to agree on the utility of the SPB throughout the school. One of the conditions for the introduction of SPB at school is the consent of $80 \%$ of the school staff (including teachers, administration, technical staff, support staff) to participate in the program. Since the SPB has a school wide approach, it is important from the outset to provide as many supporters of school support as possible and participate in the SPB program. The introduction of SPB at school should be aligned with parents and pupils.

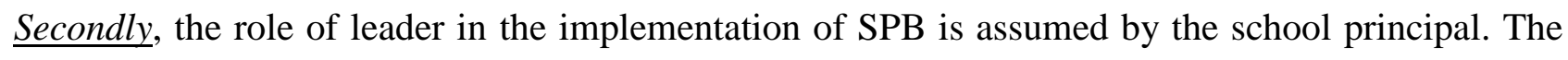
involvement of the Director plays an important role, especially in ensuring the durability of this program. The school director creates SPB team (which may be the school administration team or the school support team but is not required), who supports the director in the process of implementing and maintaining the SPB.

Thirdly, the school team is involved in a 72-hour SPB continuing education program at workplace (workplace learning), in which the entire school collects both the SPB theoretical background and practices in the new skills. The result of the SPB continuing education course is the implementation of an individual SPB plan for introducing at the concrete school.

Fourthly, in order to fully implement the SPB, close interinstitutional cooperation between schools, local municipalities, and services is necessary. 
Fifthly, the school should provide the opportunities of electronic input, storage and processing of students' behavior (positive and negative reports). Usually SPB schools have chosen "e-class" because the e-class system incorporates such data accumulation, accounting and processing capabilities and can be adapted to SPB principles.

\section{The main activities:}

The preventive activities include:

- strengthening positive communication and positive relationships between school teachers and students, removing barriers of positive communication;

- $\quad$ assessing the school environment (which disturbs and contributes to school rules);

- all school arrangements for positive behavior;

- the practice of encouragement and praise in day-to-day work, the development of a system of awarding a school for compliance;

- development of a system of the logical consequence in the case of non-compliance.

The purpose of the preventive action is to create a positive, safe climate in a school where all pupils know about what kind of behavior is expected (certain rules that are also taught at the beginning of the school year and are repeated throughout the school year are re-established), it is regularly reinforced and encouraged, there are obvious consequences that are expected if the rules are not respected. It helps students to anticipate the consequences of their actions and make the right socially acceptable choices over time.

Supportive and remedial (corrective) activities involve the use of

- supportive classroom techniques;

- the recognition of inappropriate behavior and irregularities, consistent application of gradual consequences for the unity of all teachers in the case of non-compliance;

- solving individual cases together with SPB team and involving parents;

_ problem solving involving support professionals and parents;

- inter-institutional support unit of the municipality to engage in individual cases all responsible parties;

- develop an action plan for emergencies involving breaches of rules, violence, life threats, etc. 


\section{The characteristics of the SPB implementation:}

1. The SPB is an all-embracing, universal whole-school program the implementation process of which takes into consideration democratic principles (responsibility, respect and security), gradualness and the involvement of all parties interested in the work of the school.

2. The SPB envisages development of a unified system when teaching rules to students and designing system of positive reinforcements, applying consequences, as well as establishing monitoring system for program implementation and evaluation. It consists of formulating, learning and consolidating rules throughout school year, reinforcing positive behaviour and unified personal reaction to breaches of the rules.

3. The outcome of implementing the SPB is the increase of cases of pro-social, positive, safe, respectful and responsible behaviour and the decrease of cases of problematic and antisocial behaviour at school.

4. The implementation of the SPB ensures a positive, physically and emotionally safe environment promoting the learning and facilitates students' socially emotional and moral development.

\section{The significant dimensions of assessing SPB quality:}

- administrative support to the SPB;

- $\quad$ work of the SPB team;

- implementation of the SPB methodology;

- establishment of positive environment at school;

- academic achievement;

- missed lessons;

- students' responsibility for their behaviour;

- involvement of parents;

- cooperation with the municipality specialists (outside the school);

- community interest;

- ensuring the sustainability.

Quality is ensured by conducting several mutually connected activities: focused further education of teachers and all school personnel at their workplace, regular supervisions during the SPB 
implementation, consultations as well as progress analysis which have been conducted by summarising and analysing e-data on students' behaviour. Implementation quality at school during approbation process was evaluated analysing the data summarized in e-environment. Electronic school management system 'e-class' was used. Reports of positive and negative behavior as well as other important notes (warning, reports added to personal files which were based on agreement of a teacher and SPB team) were included in the system. These summarized data give information whether the number of positive reports has a tendency to increase thus allowing to make prognosis that positive behavior in on the rise at school and this the number of negative reports decreases which allows to make conclusions that there are fewer behavior breaches at school. The summarized information helps to understand teachers' activity ignoring students' attempts or giving positive reinforcements (positive e-reports) in e-class thus encouraging students to behave in a positive manner also in the future.

\section{The publications in English:}

- Daniela, L., Nīmante, D., \& Kraǵe, G. (2014). Development of support system for decreasing social exclusion. In Teacher of the 21 st century. Newcastle upon Tyne, Cambridge Scholar Publishing.

- Nīmante, D., \& Daniela, L. (2014). Evaluation methodology of implementation of the programme 'Support to positive behaviour'. Retrieved from ResearchGate.

- Nìmante, D., \& Daniela, L. (2016). Quality Assurance of the Program „Support for Positive Behaviour" in schools of Latvia. In ECER 2016 programme. http://www.eera-ecer.de/ecerprogrammes/conference/21/contribution/38229/

- Nīmante, D., Daniela, L., \& Martinsone, B. (2017). The implementation challenges of programs "Support for positive behavior" and "Social emotional development" in children's home shelter: experience of Latvia. In ECER 2017 programme. http://www.eera-ecer.de/ecerprogrammes/conference/22/contribution/41165/

\section{THE CASE STUDY 2:}

\section{Character education program in Riga Catholic Gymnasium}

\section{Preface:}

The school community believes that the ethos of the school should built on a foundation of core values - respect, responsibility, compassion, humility, integrity, justice, moral courage, caring and fairness. These values are the basis for the social, intellectual, emotional, spiritual and moral development of 
whole child. The parents are not the only ones that need to be concerned in developing a student's character, the school and community should also have a role in this. This is why our school community needs to implement character education so that the students know the correct path they should walk on.

The reason for teaching good character is to help prepare the students to face the many opportunities and unknown dangers that are in today's society. Character education gives the students the knowledge they need to know what these dangers in society are and deal with them properly. Students need to know how to handle these pressures and character education will give them the tools that they need.

We affect students' character, for good or for ill, through everything that happens in school. Effective character education uses every part of school life as an opportunity for building good character. We encourage pupil to consider such core values as respect, responsibility, compassion, humility, integrity, justice, moral courage, caring and fairness through different activities to permeate whole curriculum, thereby developing knowledge, skills and attitudes that enable them to develop as reflective learners, achieving their full potential. As they grow to be stable, well-educated and civil adults.

And since students spend most of their time at school, it is the perfect place to instill moral values in them.

The contemporary educational process consists of three main parts: knowledge (what we know?), skills (what we can?) and character (how we behave?).

Thus the aim of Character Education programme is to develop students':

- $\quad$ Knowing (habits of the mind);

- $\quad$ Feeling - emotional intelligence (habits of the heart);

- Behavior (habits of behavior).

A holistic approach to character education develops the cognitive, emotional, and behavioral dispositions required to do the right thing and do one's best work. It fosters qualities that will help students be successful as citizens, in the workplace, and with the academic curriculum. Without performance character, we will have difficulty developing our human potential and enacting our moral values effectively. 


\section{The aim:}

To design and implement effective character education module into Riga Catholic Gymnasium that could be integrated into existing curricula to teach students character education elements such as respect; responsibility to others; compassion; humility; integrity; justice; moral courage; caring and fairness.

The Integrating Effective Character Education Programs into Riga Catholic Gymnasium include the following five objectives:

- $\quad$ Raising standards by promoting a school ethos, which is underpinned by core values that support the development of the whole child as reflective learner (to help students become smart and to help them become good);

- Development and dissemination of a Character Education Resource Manual;

- Involvement of many stakeholders in the development \& implementation of the character education program;

- $\quad$ Provision of character education training for teachers \& parents;

- Provision of International conference of urgent issues of Character education (acceding countries Latvia, Poland, Estonia, The Ukraine and Hungary).

\section{Duration:}

September 2016 - September 2018

\section{The target groups:}

- The students, teachers, staff, parents of Riga Catholic Gymnasium. The whole school community (staff, pupils, parents and community representatives) is involved in shaping the Character Education policy (450 persons).

- The students, teachers, staff, parents from other Catholic and Christian schools in Latvia (about 2000 persons).

\section{The main activities:}

The process of the developing Character Education is well planned, monitored and evaluated and celebrated in order to keep the process alive and constantly under review. The responsible persons of process control are the administration of Riga Catholic Gymnasium and task manager. 
1. The Character Education programme is established for learning about core values respect, responsibility, compassion, humility, integrity, justice, moral courage, caring and fairness, which may include:

- $\quad$ Introducing values in a programme of assemblies;

- $\quad$ One value being highlighted each month;

- The value of the month being the subject of a prominent display in the school hall and in each classroom;

- Newsletters to parents, explaining what the value of the month is and how they can be developed at home.

2. The school creates a plan for character education and defines character education clearly and comprehensively, emphasizing that it is a process that demands integration into all aspects of school life.

3. Teachers teach core ethical and performance values through their academic subjects and employ a variety of active teaching and learning strategies, and look for ways that character is potentially developed in and through everyday teaching and learning (In science, teachers can discuss the value of honesty in data, and in math, students can learn persistence by sticking with a problem until they get the right answer. History holds valuable lessons and heroes of character.)

4. The school effectively provides all students with opportunities for participation in service learning (e.g., working with the elderly; helping the homeless, those in need, or animals; or caring for the environment) and students take advantage of these opportunities and benefit from them.

5. To create a safe, caring and inclusive learning environment for every student and supports academic development. Core values appear in the school building, in the school mission statement, on the school website, in the student handbook, in the discipline code, in newsletters sent home, and at school events.

6. To encourage students to examine their own behaviour in light of the core values and challenge them to make their behaviour consistent with the core values (e.g., through journal writing, discussion of events in the classroom, one-on-one adult-student conversations about past or present behaviour).

7. To identify the core values and recognize their importance as a distinctive feature of the school.

Particular description of the process: 
At the beginning of the month (September - May) during the Eucharist or Morning prayer is declared the Value of Month.

In every class meeting students give careful consideration on this value and decide how they implement it in their relationships with classmates, schoolmates, family and environment during this month. They confirm three concrete suggestions. It helps them to interact properly with their teachers and fellow students, turning their classroom into a better learning environment.

At the end of month students examine their own behaviour in light of the month value through journal writing, discussion of events in the classroom, one-on-one adult-student conversations about past or present behaviour. Evaluation occurs in the individual, class and school level.

In the 2016/2017 school year the Value of the Month is highlighted in following subjects Religious Education, Literature, Music, Art, History.

During the school year are produced five events, which cover two values. Every event is prepared by students of single form cooperating with their subject teacher and form master.

1. Musical performance. Students+ Music teacher+ Form Master.

2. Art performance. Students+ Art teacher+ Form Master.

3. Literary performance. Students+ Literature teacher+ Form Master.

4. Erudite competition. Students+ History teacher Master+ Form master.

5. Biblical performance. Students+ History teacher Master+ Form master.

The school's summer camp will be as a summary enterprise of all values.

The adaption of core values is ensured by different ways and methods: students' exhibitions, erudite competitions, music (singing, dancing) performances, literary performances sport events, visiting exhibitions, museums, art galleries, historical and different social places in Riga, Charity work, excursions, as well as, teachers provide opportunities for students to develop their moral reasoning through discussions of ethical issues in their content areas (e.g., how lessons of history guide moral choices, how scientific discoveries have ethical implications).

\section{The outcomes:}

Students can explain why the core ethical and performance values are important, how various behaviors exemplify those values, and why some behaviors (e.g., treating others as you wish to be treated, giving your best effort) are right and others are wrong.

- develop a sense of self-identity and integrity; 
- $\quad$ reflect on social, moral, spiritual and religious choices;

seek peace, justice and truth in all pupils are encouraged:

- $\quad$ respect themselves and other people;

- $\quad$ care about the environment and the welfare of other people;

- $\quad$ think about community needs as well as their own;

- $\quad$ areas of life.

The senior researcher of the University of Latvia and postdoctoral student Manuel Joaquín Fernández González was doing a post-hoc assessment of the implementation of the program based on interviews with school students, teachers and the school leading staff. Several interesting issues about the real implementation appeared:

\section{Within the interviews with school students (grade 4-8):}

- During the first year, virtue teaching-learning happened mostly during the lessons. The second year there were several general topics or activities that students can choose (for example: library, usage of free time, folk stories from Latvia, games...). The whole class was involved in the realization of the activities (for example, the grade 8 went to the old-people house and had a theatre representation there).

- At the beginning, they used the class journal, but the second year the students were writing their thoughts in their own agenda.

- The students liked the best the projects outside the classroom, for instance the activities related to respect and compassion, to help others (for example, they went to the hospital and gave some post cards they did themselves as a gift for the sick persons).

\section{Within an interview with a teacher in preschool and primary education:}

- Positive points of the program: the focus on virtues, the system (honesty, etc.). It is important to think about these virtues. There were many materials, for example, posters with facts from real life about these virtues. There were a lot of different methods, in different contexts. However, one month is too short for really understanding one virtue. More time for each virtue is necessary.

- The teachers liked to use the practical aspects: for example, for improving the virtue of order, studnets and teachers looked together at the students' journals and homework notebooks for highlighting the most positive examples of the virtue of order there, not for criticizing each other. 
- A seminar for teachers was very appreciated, and another one for parents also received good feedback. Joint discussions with other teachers about the implementation of the program were missing. It was difficult, because there is a lot of things to do.

\section{Within an interview with a school leading staff:}

- Nine virtues are too much in a year. There is not time to go deeper and to have some feedback and reflection about them. The school has a lot of event by default (country feasts, religious feasts, career education activities...). The ideal would be one virtue per two months: September-October / November-December / January-February / March-April / etc. and then maybe a final event, if any. So, four virtues per year (maybe two close virtues could be put together).

- In secondary education the practical aspects this year were most important: everything was done in a practical way, not through lectures. Of course, some theoretical knowledge could help, but the real important thing is the practice. For example, about respect, they wrote their own theatre plays. One of the topics was "respecting time". Youngsters should learn to respect the time, their own time (not to spend it in computer or telephone games) and the time of others. They were learning through the events that were not so positive.

- In 2017-2018, an interesting new activity was the radio program prepared by the students themselves. They spoke in their program about the virtue of the month.

Summarizing the most relevant aspects of these good practices and applying them to a future character education program at school:

- The program should have the consent of $80 \%$ of the school staff (including teachers, administration, technical staff, support staff) to participate in the program, and be aligned with parents and pupils. The implementation should be assumed by the school principal

- The program could be introduced through a continuing workplace learning program for teachers (6 to 32 hours), resulting in a personalized plan for character education at school.

- The plan should be clear and foresee time enough to develop each habit (2 months). Teachers should have time to reflect and discuss among them at least twice a year.

- The teaching and learning methods should include class activities, and also practical activities out of the school with a social component. Reflection tool for students should be included (journal, personal mentoring conversations, or other)

- The implementation could be supported by $\boldsymbol{e}$-class system for facilitating communication with parents, and by e-leaning systems (such as uzdevumi.lv) for facilitating teaching and learning.

- The school space should reflect the educational priorities (posters) 


\section{Part 3}

\section{Benchmarking of TC\&CE}

\section{Section 3.1 \\ SOME EXISTING TC\&CE INITIATIVES IN UK AND USA}

\section{Some existing TC\&CE initiatives in UK}

The existing TC\&CE initiatives (projects, courses, programmes, etc.) for teachers' professional competence development:

1. In 2016, the School of Education at the University of Birmingham introduced the world's first MA programme in Character Education. This distance learning programme is taught by expert members of the Jubilee Centre for Character and Virtues. Course type: postgraduate, continuing professional development, distance learning. Duration: 3 years.

https://www.birmingham.ac.uk/postgraduate/courses/distance/edu/character-education.aspx

2. The free online course 'Building Character through Youth Social Action' provides an opportunity to learn about the history of social action, and how youth social action can help build character in young people. This course is delivered in partnership with the University of Birmingham and FutureLearn and is open for anyone with an interest in youth work and working with young people. Duration: over two weeks.

https://www.futurelearn.com/courses/youth-social-action

3. The free online course 'What is Character? Virtue Ethics in Education' debates in the field of character and character education. The course explores virtues and the role they play in helping both individuals and society flourish. Tapping into an increasing interest in character education and answering important questions such as, what is character and character education, why is it important and can it be taught? Duration: two weeks.

\section{https://www.futurelearn.com/courses/what-is-character}

Other TC\&CE initiatives (projects, conferences, workshops, documents, etc.) for children, youth, parents, teachers, etc. 
1. The research project "The Psychological Development of Character: Emotion, Identity and Phronesis" conducted by the Jubilee Centre for Character and Virtues of the University of Birmingham. http://www.jubileecentre.ac.uk/1756/projects/current-projects/phronesis

2. The research project "Virtues in the Professions" conducted by the Jubilee Centre for Character and Virtues of the University of Birmingham.

http://jubileecentre.ac.uk/1595/projects/published-research/virtues-in-the-professions

3. Character Education Research conducted by the Jubilee Centre for Character and Virtues of the University of Birmingham. http://jubileecentre.ac.uk/1758/projects/published$\underline{\text { research/character-education-research }}$

4. The research project "Teaching Character through Subjects" http://www.jubileecentre.ac.uk/1676/character-education/resources/teaching-character-through$\underline{\text { subjects }}$

5. The research project "The Schools of Virtue" http://www.jubileecentre.ac.uk/1589/projects/current-projects/schools-of-virtue

6. The research project "The Character Education in UK Schools" http://www.jubileecentre.ac.uk/1571/projects/previous-work/character-education-in-uk-schools

7. My Character Feasibility Study http://www.jubileecentre.ac.uk/1575/projects/previouswork/my-character

8. Character and Public Policy: Educating for an Ethical Life, University of Birmingham, December 14-15, 2012. The first annual conference of the Jubilee Centre for Character and Virtues, University of Birmingham. http://www.jubileecentre.ac.uk/484/conferences/characterand-public-policy

9. Can Virtue be Measured?, Oriel College, Oxford, January 9-11, 2014. The second annual conference of the Jubilee Centre for Character and Virtues, University of Birmingham. http://www.jubileecentre.ac.uk/485/conferences/can-virtue-be-measured

10. Varieties of Virtue Ethics in Philosophy, Social Science and Theology, Oriel College, Oxford, January 8-10, 2015. The third annual conference of the Jubilee Centre for Character and Virtues, University of Birmingham. http://www.jubileecentre.ac.uk/502/conferences/varietiesof-virtue-ethics 
11. Cultivating Virtues: Interdisciplinary Approaches, Oriel College, Oxford, January 7-9, 2016. The fourth annual conference of the Jubilee Centre for Character and Virtues, University of Birmingham. http://www.jubileecentre.ac.uk/1643/conferences/cultivating-virtues

12. Character and Virtue in the Professions: An Interdisciplinary Conference, University of Birmingham, June 2-4, 2016. http://www.jubileecentre.ac.uk/1673/conferences/character-andvirtue-in-the-professions

13. Character, Wisdom and Virtue, Oriel College, Oxford, January 5-7, 2017. The fifth annual conference of the Jubilee Centre for Character and Virtues, University of Birmingham. http://www.jubileecentre.ac.uk/1674/conferences/character-wisdom-and-virtue

14. Virtues in the Public Sphere, Oriel College, Oxford, January 4-6, 2018. The sixth annual conference of the Jubilee Centre for Character and Virtues, University of Birmingham. http://www.jubileecentre.ac.uk/1723/conferences/virtues-in-the-public-sphere

15. Educating Character Through the Arts. University of Birmingham Conference Centre, 19th-21st July, 2018. http://www.jubileecentre.ac.uk/1743/conferences/educating-character-through-the$\underline{\operatorname{arts}}$

16. Virtues: Local or Universal? Oriel College, Oxford, January 3-5, 2019. The seventh annual conference of the Jubilee Centre for Character and Virtues, University of Birmingham. http://www.jubileecentre.ac.uk/1779/conferences/virtues-local-or-universal-

17. The Jubilee Centre for Character and Virtues has developed a series of resources to promote character education for teachers and other education stakeholders http://www.jubileecentre.ac.uk/1610/character-education/ and for parents http://www.jubileecentre.ac.uk/1764/character-education/parent-resources

18. A Framework for Character Education in Schools. http://www.jubileecentre.ac.uk/userfiles/jubileecentre/pdf/charactereducation/Framework\%20for\%20Character\%20Education.pdf

19. Statement on Teacher Education and Character Education. http://www.jubileecentre.ac.uk/userfiles/jubileecentre/pdf/charactereducation/Statement_on_Teacher_Education_and_Character_Education.pdf

20. Teaching Character through the Curriculum. A guide to educating the virtues through and within 14 secondary school subjects.

http://www.jubileecentre.ac.uk/userfiles/jubileecentre/pdf/TeachingCharacterThroughtheCurric ulum.pdf 
21. Schools of Character. http://www.jubileecentre.ac.uk/userfiles/jubileecentre/pdf/charactereducation/SchoolsOfCharacterPDF.pdf

\section{Some existing TC\&CE initiatives in USA}

\section{The existing TC\&CE initiatives (projects, courses, programmes, etc.) for teachers' professional competence development:}

Character.org offers multiple support and training opportunities for K-12 schools, districts, and state-wide initiatives. These range from one day to multi-year assistance:

\section{http://character.org/training/institutes-and-workshops/}

1. Character.org 11 Principles Sourcebook Training Seminar (1-day or 2-day). Character.org trainers provide an overview of the 11 Principles of Effective Character, with significant focus on the foundational steps for systemic change. This work includes looking at existing school culture and "hidden curriculum," the importance of establishing core ethical values used to guide judgment and decision-making, and understanding how character is formed.

2. Eleven Principles Sourcebook Leadership Institute (1-day or 2-day). The Character.org Leadership Institute is an initial training in Character.org's Eleven Principles of Effective Character Education, customized to help school leaders learn how to move the initiative forward in their schools and what might be major areas for planning. This is an excellent starter format for a school district wishing to initiate effective character education across multiple school sites. The attending teams, which may be the character education committee, should include the principal, other school administrators, teacher-leaders, and community members and students, as appropriate. Teams of 5-9 participants are ideal. This is a great way to build a "critical mass" of supporters. It also works well when schools cannot do a staff-wide training because of limited professional development release days.

3. Regional Institutes. Regional Institutes are similar to Eleven Principles Sourcebook Training Seminar, offering foundational coverage of the Eleven Principles. Participants come to a central location for the training day and are encouraged to come in teams. The Institute is held every year at Character.org's Forum. It has also been held in areas that share resources across districts. At times, Institute participants go back to their schools so excited that they will bring Character.org to their schools to provide a full-staff experience.

4. Skill Workshops. Skill workshops are three-hour training opportunities customized for the needs of a school's action plan. These workshops typically provide the "how to" training for areas that 
have emerged as the staff becomes more familiar with character education. Examples of workshop topics include class meetings; service learning; problem-solving; discipline; conflict resolution; SEL skills, i.e., active listening, I-statements, and role-plays.

5. Collegial Follow-Up Sessions. Customized and focused discussion with school teams and Character.org leadership addresses specific topics and process identified by the school sometime after initial professional development takes place. Support for class meetings, service learning, and development or implementation techniques for portions of the 11 principles are often addressed. These are $1 / 2$ day sessions.

Other TC\&CE initiatives (projects, conferences, workshops, documents, etc.) for children, youth, parents, teachers, etc.

1. The three case studies demonstrates the positive effects of implementing effective character education into schools. http://character.org/key-topics/what-is-character-education/case-studies/

2. The 11 Principles of Effective Character Education are the cornerstone of Character.org's philosophy on effective character education. Each principle outlines vital aspects of character education initiatives that should not be overlooked in program implementation. http://character.org/more-resources/11-principles/

3. Character.org helps character educators nation-wide share effective lessons, strategies and best practices. Each lesson plan relates to Character.org's 11 Principles of Effective Character Education. http://character.org/lessons/lesson-plans/

4. 2018 National Forum on Character. Washington Marriott Wardman Park, Washington, DC. October 5-6, 2018. http://character.org/conference/

5. Center for Character and Citizenship (CCC). https://characterandcitizenship.org/

6. Association for Moral Education (AME). http://www.amenetwork.org/

7. Center for Character and Social Responsibility (CCSR). http://www.bu.edu/ccsr/

8. The Character Project. Wake Forest University. http://www.thecharacterproject.com/

9. The Duckworth Lab. https://characterlab.org/

10. The Center for the 4th and 5th R (Respect and Responsibility). http://www2.cortland.edu/centers/character

11. Authentic Happiness. https://www.authentichappiness.sas.upenn.edu/

12. Character Plus. http://www.edplus.org/domain/133 
13. A new science of virtues. A project of the University of Chicago. http://scienceofvirtues.org/

14. The self, motivation, and virtue project. http://smvproject.com/

\section{Section 3.2}

\section{SOME POSSIBILITIES FOR TRANSFER AND ADAPTATION OF UK and USA materials and programs}

\begin{tabular}{|c|c|c|c|c|}
\hline Name & Website & Place & $\begin{array}{c}\text { Relevant } \\
\text { aspects }\end{array}$ & $\begin{array}{c}\text { The possibilities for transfer } \\
\text { and adaptation }\end{array}$ \\
\hline $\begin{array}{l}\text { The Jubilee } \\
\text { Centre for } \\
\text { Character and } \\
\text { Virtues (JCCV) }\end{array}$ & $\begin{array}{l}\text { http://www.jubileec } \\
\text { entre.ac.uk/ }\end{array}$ & $\begin{array}{l}\text { UK, } \\
\text { Birmingham } \\
\text { University }\end{array}$ & $\begin{array}{l}\text { Research } \\
\text { projects. } \\
\text { Open } \\
\text { source } \\
\text { materials } \\
\text { for schools }\end{array}$ & $\begin{array}{l}\text { Translation and dissemination of } \\
\text { the documents "Statement on } \\
\text { teacher education and character } \\
\text { education" and "A framework for } \\
\text { character education at schools" }\end{array}$ \\
\hline $\begin{array}{l}\text { Center for } \\
\text { Character and } \\
\text { Citizenship } \\
\text { (CCC) }\end{array}$ & $\begin{array}{l}\text { https://characterand } \\
\text { citizenship.org/ }\end{array}$ & $\begin{array}{l}\text { USA (St. } \\
\text { Louis): } \\
\text { University of } \\
\text { Missoury- } \\
\text { ST. Louis }\end{array}$ & $\begin{array}{l}\text { Congresses, } \\
\text { conferences } \\
\text { materials... }\end{array}$ & $\begin{array}{l}\text { Useful "Guidelines for Effective } \\
\text { Practice" at } \\
\text { https://characterandcitizenship.org } \\
\text { /researchers/18-what-works-in- } \\
\text { character-education-report-for- } \\
\text { practitioners }\end{array}$ \\
\hline $\begin{array}{l}\text { Center for } \\
\text { Character and } \\
\text { Social } \\
\text { Responsibility } \\
\text { (CCSR) }\end{array}$ & $\begin{array}{l}\text { http://www.bu.edu/ } \\
\text { ccsr/ }\end{array}$ & $\begin{array}{l}\text { USA: Boston } \\
\text { University }\end{array}$ & $\begin{array}{l}\text { (MOOC): } \\
\text { Ethical } \\
\text { Leadership: } \\
\text { Character, } \\
\text { Civility and } \\
\text { Community }\end{array}$ & $\begin{array}{l}\text { Downloadable Lesson Plans at } \\
\text { http://www.bu.edu/ccsr/resources/ } \\
\text { lesson-plans/ }\end{array}$ \\
\hline $\begin{array}{l}\text { Character } \\
\text { Project }\end{array}$ & $\begin{array}{l}\text { http://www.thechar } \\
\text { acterproject.com/ }\end{array}$ & $\begin{array}{l}\text { USA (North } \\
\text { Carolina): } \\
\text { Wake Forest } \\
\text { University }\end{array}$ & $\begin{array}{l}\text { Research } \\
\text { grants, } \\
\text { academic } \\
\text { resources }\end{array}$ & $\begin{array}{l}\text { http://studyofcharacter.com/resour } \\
\text { ces (online texts, links to centres, } \\
\text { etc) }\end{array}$ \\
\hline $\begin{array}{l}\text { The Duckworth } \\
\text { Lab }\end{array}$ & $\begin{array}{l}\text { https://characterlab. } \\
\text { org/ }\end{array}$ & $\begin{array}{l}\text { USA: } \\
\text { University of } \\
\text { Pennsylvania }\end{array}$ & $\begin{array}{l}\text { Grit scale } \\
\text { (book } \\
2016 \text { ) }\end{array}$ & $\begin{array}{l}\text { Playbooks (teacher resources for } \\
\text { cultivating character) } \\
\text { https://www.characterlab.org/play } \\
\underline{\text { books }}\end{array}$ \\
\hline $\begin{array}{l}\text { The Center for } \\
\text { the } 4^{\text {th }} \text { and } 5^{\text {th }} \mathrm{R} \\
\text { (Respect and } \\
\text { Responsibility) }\end{array}$ & $\begin{array}{l}\text { http://www2.cortla } \\
\underline{\text { nd.edu/centers/char }} \\
\underline{\text { acter }}\end{array}$ & $\begin{array}{l}\text { USA: State } \\
\text { University of } \\
\text { New York } \\
\text { (SUNY } \\
\text { Cortland }\end{array}$ & $\begin{array}{l}\text { Smart \& } \\
\text { Good } \\
\text { Schools } \\
\text { Resources } \\
\text { for schools } \\
\text { and } \\
\text { teachers }\end{array}$ & $\begin{array}{l}\text { Materials for sharing with } \\
\text { colleagues, and apply in school's } \\
\text { work } \\
\text { (http://www2.cortland.edu/centers } \\
\text { /character/resources/SandG/index. } \\
\text { dot). }\end{array}$ \\
\hline
\end{tabular}




\begin{tabular}{|c|c|c|c|c|}
\hline $\begin{array}{l}\text { Authentic } \\
\text { Happiness }\end{array}$ & $\begin{array}{l}\text { https://www.authen } \\
\text { tichappiness.sas.up } \\
\text { enn.edu/ }\end{array}$ & $\begin{array}{l}\text { USA: } \\
\text { University of } \\
\text { Pennsylvania }\end{array}$ & $\begin{array}{l}\text { Resources, } \\
\text { questionnai } \\
\text { res }\end{array}$ & $\begin{array}{l}\text { List of } 30 \text { questionnaires could be } \\
\text { used for character evaluation } \\
\text { (e.g., PERMA questionnaire - } \\
\text { Measures Flourishing; Gratitude } \\
\text { survey; Grit survey...). Could be } \\
\text { translated in Latvian: } \\
\text { https://www.authentichappiness.s } \\
\text { as.upenn.edu/testcenter }\end{array}$ \\
\hline $\begin{array}{l}\text { Character } \\
\text { Education } \\
\text { Partnership } \\
\text { (CEP) }\end{array}$ & http://character.org/ & $\begin{array}{l}\text { USA, } \\
\text { Washington }\end{array}$ & $\begin{array}{l}11 \\
\text { Principles } \\
\text { of Effective } \\
\text { Character } \\
\text { Education }\end{array}$ & $\begin{array}{l}\text { The } 11 \text { principles could be } \\
\text { translated into Latvian. Useful } \\
\text { lesson plans for teacher } \\
\text { (http://character.org/lessons/lesso } \\
\text { n-plans/); assessment tools } \\
\text { (http://character.org/more- } \\
\text { resources/assessment-tools/) }\end{array}$ \\
\hline Character Plus & $\begin{array}{l}\text { http://www.edplus. } \\
\text { org/domain/133 }\end{array}$ & $\begin{array}{l}\text { USA: Saint } \\
\text { Louis }\end{array}$ & $\begin{array}{l}\text { Online } \\
\text { resources }\end{array}$ & $\begin{array}{l}\text { The list of the existing online } \\
\text { resources } \\
\text { https://www.edplus.org/domain/1 } \\
\underline{82}\end{array}$ \\
\hline
\end{tabular}




\section{Part 4}

\section{Developing pupils' intrapersonal competencies and character education at school: bases for a support program for teachers}

\section{Section 4.1 \\ SWOT ANALYSIS OF TC\&CE IN LATVIA: SYNTHESIS OF CONTEXT ANALYSIS AND BENCHMARKING}

\begin{tabular}{|l|l|}
\hline Strengths & $\begin{array}{l}\text { The understanding of transversal competences in Latvia is improved within } \\
\text { the ESF project "Competence-based approach in the educational content" - } \\
\text { School } 2030 \text { (2016-2021) and the EC project ,European Qualifications } \\
\text { Framework - National Coordination Point". } \\
\text { 2. In 2015, the work group created by the National Center for Education } \\
\text { (VISC) of the Republic of Latvia elaborated "moral upbringing (virtue } \\
\text { education) guidelines" offering the following virtues for inclusion in the } \\
\text { guidelines: respect, solidarity, justice, virtue, fairness, freedom, } \\
\text { responsibility, studiousness, caring, empathy, moderation and courage. The } \\
\text { guidelines also feature concepts such as life, work, and culture. } \\
\text { 3. There are many national and regional level centres, which provide various } \\
\text { teachers' training and professional development programmes including such } \\
\text { issues as virtue education and transversal competences. } \\
\text { 4. All teachers' training and professional development programmes on virtue } \\
\text { education as well as teaching aids, materials and teaching/learning and } \\
\text { upbringing methods should be elaborated in accordance with the Cabinet of } \\
\text { Ministers' regulation No } 480 \text { "Guidelines for the upbringing (virtue } \\
\text { education) of learners and the procedure for evaluating information, }\end{array}$ \\
\hline
\end{tabular}




\begin{tabular}{|c|c|}
\hline & $\begin{array}{l}\text { teaching aids, materials and teaching/learning and upbringing methods" } \\
\text { (adopted in 2016) }\end{array}$ \\
\hline Weaknesses & $\begin{array}{l}\text { 1. There is a lack of unified understanding of character education in Latvia. } \\
\text { 2. There is a lack of teachers' training and professional development } \\
\text { programmes on character education. }\end{array}$ \\
\hline Opportunities & $\begin{array}{l}\text { 1. There are some institutional efforts of elaboration and implementation of } \\
\text { character education programmes (for instance, in Riga Catholic } \\
\text { Gymnasium). } \\
\text { 2. The understanding of character education in Latvia could be improved } \\
\text { within various research projects, for instance, Erasmus+ project "Shaping } \\
\text { Characters" (2015-2017), the UL's project "Teachers' ethics, development } \\
\text { of transversal and socio-emotional competences and characher education to } \\
\text { promote quality of education" (2016-2018), the postdoctoral research } \\
\text { project "Modernization of school education in Latvia through an innovative } \\
\text { research-based program on } 21 \text { st century competences and virtue ethics } \\
\text { development supported by a virtual campus (ARETE-school)" (2017-2020), } \\
\text { etc. } \\
\text { The existing TC\&CE in UK and USA could be used as inspiring sources for } \\
\text { elaboration and implementation of character education programmes in } \\
\text { Latvia. Some possibilities for transfer and adaptation of UK and USA } \\
\text { materials and programs are proposed. }\end{array}$ \\
\hline Threats & $\begin{array}{l}\text { 1. Because of current educational reforms, teachers are overloaded with new } \\
\text { information and need to concentrate in the new competence approach and } \\
\text { may lack of time for a course about character education (delivery it should } \\
\text { be efficient and adapted to teachers' availability). } \\
\text { 2. It will be difficult to find teacher trainers with enough time and } \\
\text { competence in the field of character education to implement the training } \\
\text { course (course leaders should be well prepared and motivated). } \\
\text { 3. Some teachers would be reluctant to use the concepts "virtue education" or } \\
\text { "character education" because of different connotations (maybe the word } \\
\text { "education of good habits", used in School2030 documents, should be used } \\
\text { instead - in Latvian: "labu ieradumu veidošanās"). }\end{array}$ \\
\hline
\end{tabular}

